Journal of Applied Pharmaceutical Science Vol. 5 (10), pp. 044-047, October, 2015

Available online at http://www.japsonline.com

DOI: $10.7324 / \mathrm{JAPS} .2015 .501008$

ISSN 2231-3354 (cC) EY-NC-SA

\title{
Callus extract of Ipomoea mauritiana show analgesic and antihyperglycemic activity in Swiss albino mice
}

\author{
Saiful Islam ${ }^{1}$, Md Rasel Ahmed ${ }^{1}$, Rahat Al-Mahamud ${ }^{1}$, Shahnaz Rahman ${ }^{1}$, F.M. Safiul Azam ${ }^{1}$, Rownak Jahan ${ }^{1}$, \\ Mohammed Rahmatullah ${ }^{2} *$ \\ ${ }^{1}$ Department of Biotechnology \& Genetic Engineering, University of Development Alternative, Dhaka, Bangladesh. \\ ${ }^{2}$ Department of Pharmacy, University of Development Alternative, Dhaka, Bangladesh .
}

\begin{tabular}{|c|c|}
\hline ARTICLE INFO & ABSTRACT \\
\hline $\begin{array}{l}\text { Article history: } \\
\text { Received on: } 08 / 07 / 2015 \\
\text { Revised on: } 22 / 07 / 2015 \\
\text { Accepted on: } 10 / 08 / 2015 \\
\text { Available online: } 28 / 10 / 2015\end{array}$ & $\begin{array}{l}\text { Callus can be a viable alternative to obtain important phytochemicals and analyze crude extract for } \\
\text { pharmacological activities rather than going the cumbersome way of collecting and destroying possibly } \\
\text { endangered plants. In this study, callus was produced using nodal explant of Ipomoea mauritiana, and methanol } \\
\text { extract of dried and powdered callus was evaluated for its analgesic and antihyperglycemic potential. The extract, } \\
\text { when administered to Swiss albino mice at doses of } 50,100,200 \text { and } 400 \mathrm{mg} \text { per kg significantly reduced the }\end{array}$ \\
\hline $\begin{array}{l}\text { Key words: } \\
\text { Analgesic, Ipomoea } \\
\text { mauritiana, } \\
\text { antihyperglycemic, callus, } \\
\text { Convolvulaceae }\end{array}$ & $\begin{array}{l}53.3 \% \text {, respectively. A standard analgesic drug, aspirin, at doses of } 200 \text { and } 400 \mathrm{mg} \text { per } \mathrm{kg} \text {, reduced the number } \\
\text { of writhings by } 40.0 \text { and } 46.7 \% \text {, respectively. In oral glucose tolerance tests conducted with glucose-loaded mice, } \\
\text { the extract at doses of 50,100, } 200 \text { and } 400 \mathrm{mg} \text { per kg significantly reduced blood glucose levels by } 35.1,42.5 \text {, } \\
53.6 \text {, and } 58.8 \% \text {. In comparison, a standard antihyperglycemic drug, glibenclamide, at a dose of } 10 \mathrm{mg} \text { per } \mathrm{kg} \\
\text { reduced blood glucose levels by } 60.7 \% \text {. Our study indicates that methanol extract of callus of } \text { I. mauritiana can } \\
\text { be used to alleviate pain and high blood sugar levels. }\end{array}$ \\
\hline
\end{tabular}

\section{INTRODUCTION}

Ipomoea mauritiana Jacq. (Convolvulaceae) is a vinous plant known in English as giant potato and in Bangladesh as bhui kumra. It can be found in many parts of the world. The plant has ethnomedicinal importance. Tubers are taken orally to alleviate spinal cord pain and to increase milk in nursing mothers by the Garo tribal community of Madhupur in Tangail district, Bangladesh (Jahan et al., 2013). In Naogaon district, Bangladesh, folk medicinal practitioners use tubers to treat tuberculosis and to increase appetite (Anzumi et al., 2014). In two Mouzas of Kurigram district, Bangladesh, folk medicinal practitioners use the leaves of the plant to treat leucorrhea and diabetes with obesity (Azad et al., 2014). In Bagerhat district, banglades, tubers are used as nutritive, diuretic, to improve voice, to increase strength, as sexual stimulant, to increase sperm count and lactation, to treat skin assuming a different colour as in jaundice,

\footnotetext{
* Corresponding Author
}

Email: rahmatm@uoda.edu.bd as blood purifier and for treatment of biliary disorders and burning sensations in the body (Walid et al., 2013). Folk medicinal practitioners of Shitol Para village in Jhalokati district, Bangladesh use leaves, stems and roots of the plant to treat infrequent urination, to reduce excessive bile secretion, to increase strength, to increase lactation in nursing mothers and to treat pain in bones and gastric pain (Rahmatullah et al., 2010a). Medicinal plants of Bangladesh are comparatively undocumented and not studied in any detail as to their pharmacological potentials. Since diabetes and pain are very common afflictions in Bangladesh, we had been systematically screening medicinal plants of the country as to their pain alleviating and antihyperglycemic properties (Morshed et al., 2010; Rahmatullah et al., 2010b; Ahmed et al., 2011; Shahreen et al., 2012; Haque et al., 2013; Rahmatullah et al., 2013a,b; Ghosh et al., 2014; Hossain et al., 2014; Jahan et al., 2014; Rahman et al., 2014; Tazin et al., 2014). Folk medicinal and other types of traditional medicinal practitioners use medicinal plants in their formulations but most often disregard the conservation status of the plants. Moreover, if roots, tubers or rhizomes of a medicinal plant are necessary in traditional medicinal formulations, the whole plant is uprooted thus destroying the plant. 
This is done with scant regard to the plant's recultivation, thus making such plants becoming rapidly endangered. One way out of this impasse is to conduct pharmacological studies on calluses produced from nodal explants of the plant. If calluses can be seen to give the desired pharmacological effect or have the requisite phytochemical(s), they can serve the purpose of various plant parts including underground parts, and such calluses can be obtained within a relatively small space in the laboratory or industry and so negating the uprooting of plants and as a result endangering them. Traditional practitioners can substitute whole plants for calluses. Callus culture and concomitant pharmacological studies are rapidly gaining attention of scientists. In vitro callus and in vivo leaf extract of Gymnema sylvestre has been shown to stimulate $\beta$-cells regeneration and anti-diabetic activity in Wistar rats (Ahmed et al., 2010). Gymnemic acid, the active antidiabetic principle of Gymnema sylvestre has been obtained from calluses (Ali Ahmed et al., 2009). Antidiabetic activity has been seen in callus cultures of onion (Kelkar et al., 2001). The objective of the present study was to determine the analgesic and antihyperglycemic potential of methanol extract of calluses produced from nodal explants of I. mauritiana.

\section{MATERIALS AND METHODS}

\section{Plant material collection}

Explants of $I$. mauritiana were collected during November 2013 from Natore, Bangladesh. Calluses were produced from March to July 2014 using procedures as described before (Islam et al., 2014). The age of calluses was 40 days.

\section{Preparation of methanolic extract of calluses}

Calluses were cut into small pieces, air-dried in the shade, and $25 \mathrm{~g}$ of dried and powdered calluses were extracted with methanol (w:v ratio of $1: 5$, final weight of the extract $3.367 \mathrm{~g}$ ).

\section{Chemicals and Drugs}

Glibenclamide, aspirin, and glucose were obtained from Square Pharmaceuticals Ltd., Bangladesh. All other chemicals were of analytical grade.

\section{Animals}

Swiss albino mice, which weighed between $14-18 \mathrm{~g}$ were used in the present study. The animals were obtained from International Centre for Diarrhoeal Disease Research, Bangladesh (ICDDR,B). The animals were acclimatized for three days prior to actual experiments. The study was conducted following approval by the Institutional Animal Ethical Committee of University of Development Alternative, Dhaka, Bangladesh.

\section{Analgesic activity evaluation through abdominal writhing test}

Analgesic activity of methanolic extract of calluses (MEIMC) was examined as previously described (Shanmugasundaram and Venkataraman, 2005). Mice were divided into seven groups of five mice each. Group 1 served as control and was administered vehicle only. Groups 2 and 3 were orally administered the standard analgesic drug aspirin at doses of 200 and $400 \mathrm{mg}$ per $\mathrm{kg}$ body weight, respectively. Groups 4-7 were administered MEIMC at doses of 50, 100, 200 and $400 \mathrm{mg}$ per $\mathrm{kg}$ body weight, respectively. Following a period of 60 minutes after oral administration of standard drug or MEIMC, all mice were intraperitoneally injected with $1 \%$ acetic acid at a dose of $10 \mathrm{ml}$ per $\mathrm{kg}$ body weight. A period of 5 minutes was given to each animal to ensure bioavailability and onset of chemically induced irritation of acetic acid (Akter et al., 2014), following which period, the number of abdominal constrictions (writhings) was counted for $10 \mathrm{~min}$. The percent inhibitions of abdominal constrictions were calculated according to the formula given below.

\section{Percent inhibition $=\left(1-\mathrm{W}_{\mathrm{e}} / \mathrm{W}_{\mathrm{c}}\right) \times 100$}

Where: $\mathrm{W}_{\mathrm{e}}$ and $\mathrm{W}_{\mathrm{c}}$ represents the number of writhings in aspirin or MEIMC administered mice (Groups 2-7), and control mice (Group $1)$, respectively.

\section{Oral glucose tolerance tests for evaluation of antihyperglycemic activity}

Oral glucose tolerance tests (OGTT) were carried out as per the procedure previously described by Joy and Kuttan (1999) with minor modifications. Briefly, fasted mice were grouped into six groups of five mice each. The various groups received different treatments like Group 1 received vehicle (1\% Tween 80 in water, $10 \mathrm{ml} / \mathrm{kg}$ body weight) and served as control, Group 2 received standard drug (glibenclamide, $10 \mathrm{mg} / \mathrm{kg}$ body weight). Groups 3-6 received methanolic callus extract (MEIMC) at doses of 50, 100, 200 and $400 \mathrm{mg}$ per $\mathrm{kg}$ body weight. All substances were orally administered.

Following a period of one hour, all mice were orally administered $2 \mathrm{~g}$ glucose $/ \mathrm{kg}$ of body weight. Blood samples were collected 120 minutes after the glucose administration through puncturing heart. Blood glucose levels were measured by glucose oxidase method (Venkatesh et al., 2004). The percent lowering of blood glucose levels were calculated according to the formula described below.

Percent lowering of blood glucose level $=\left(1-\mathrm{W}_{\mathrm{e}} / \mathrm{W}_{\mathrm{c}}\right) \mathrm{X} 100$, where $\mathrm{W}_{\mathrm{e}}$ and $\mathrm{W}_{\mathrm{c}}$ represents the blood glucose concentration in glibenclamide or MEIMC administered mice (Groups 2-6), and control mice (Group 1), respectively.

\section{Acute toxicity test}

Acute toxicity test was conducted as previously described (Ganapaty et al., 2002). Mice were divided into nine groups, each group consisting of six animals. Group 1 was given $1 \%$ Tween 80 in normal saline ( $2 \mathrm{ml}$ per $\mathrm{kg}$ body weight). The other eight groups (Groups 2-9) were administered, respectively, 100, 200, 300, 600, 800, 1000, 2000 and $3000 \mathrm{mg}$ of MEIMC per $\mathrm{kg}$ body weight. All animals were closely observed for the next 8 hours to notice any behavioral changes or mortality and were kept under close observation for the next two weeks. 


\section{Statistical analysis}

Experimental values are expressed as mean \pm SEM. Independent Sample t-test was carried out for statistical comparison. Statistical significance was considered to be indicated by a p value $<0.05$ in all cases (Hossain et al., 2014).

\section{RESULTS AND DISCUSSION}

\section{Toxicity evaluation}

The crude extract (MEIMC) did not show any toxicity in mice even at the highest dose tested. There were no changes in behavioral pattern and mortality was not observed.

\section{Analgesic activity evaluation results}

MEIMC exhibited dose-dependent and significant analgesic activity in acetic acid-induced writhing tests. At doses of 50, 100, 200 and $400 \mathrm{mg}$ per $\mathrm{kg}$, administration of MEIMC led to respectively, 23.3, 33.3, 43.3, and 53.3\% reductions in the number of writhings in experimental mice compared to control animals. A standard analgesic drug, aspirin, when administered to mice at doses of 200 and $400 \mathrm{mg}$ per $\mathrm{kg}$, led to, respectively, 40.0 and $46.7 \%$ reductions in the number of writhings. Thus, at the highest dose of $400 \mathrm{mg}$ per $\mathrm{kg}$, MEIMC administration showed better analgesic activity than $400 \mathrm{mg}$ aspirin per $\mathrm{kg}$, and a dose of 200 mg MEIMC showed better analgesic activity than $200 \mathrm{mg}$ per $\mathrm{kg}$ aspirin. The results are shown in Table 1 and suggest that the methanolic crude extract of MEIMC can be used for analgesic purposes.

Table 1: Analgesic effect of crude methanol extract of I. mauritiana callus (MEIMC) in acetic acid-induced pain model mice.

\begin{tabular}{lccc}
\hline Treatment & $\begin{array}{c}\text { Dose (mg/kg } \\
\text { body weight) }\end{array}$ & $\begin{array}{c}\text { Mean number of } \\
\text { abdominal } \\
\text { constrictions }\end{array}$ & $\begin{array}{c}\% \\
\text { inhibition }\end{array}$ \\
\hline Control & $10 \mathrm{ml}$ & $6.0 \pm 0.32$ & - \\
Aspirin & $200 \mathrm{mg}$ & $3.6 \pm 0.24$ & $40.0^{*}$ \\
Aspirin & $400 \mathrm{mg}$ & $3.2 \pm 0.37$ & $46.7^{*}$ \\
(MEIMC) & $50 \mathrm{mg}$ & $4.6 \pm 0.51$ & $23.3^{*}$ \\
(MEIMC) & $100 \mathrm{mg}$ & $4.0 \pm 0.55$ & $33.3^{*}$ \\
(MEIMC) & $200 \mathrm{mg}$ & $3.4 \pm 0.40$ & $43.3^{*}$ \\
(MEIMC) & $400 \mathrm{mg}$ & $2.8 \pm 0.37$ & $53.3^{*}$ \\
\hline
\end{tabular}

All administrations (aspirin and extract) were made orally. Values represented as mean $\pm \mathrm{SEM},(\mathrm{n}=5) ; * P<0.05$; significant compared to control.

The analgesic activity of crude ethanol extract of whole plants of I. mauritiana has been previously reported (Monjur-AlHossain et al., 2013). Our results suggest that the crude callus extract can substitute for the whole plant regarding analgesic activity effects.

\section{Antihyperglycemic activity evaluation results}

In oral glucose tolerance tests, MEIMC when administered at doses of 50, 100, 200 and $400 \mathrm{mg}$ per kg body weight, dose-dependently and significantly reduced the amount of blood glucose in experimental animals. At these four doses, MEIMC, respectively, decreased blood glucose levels by 35.1, $42.5,53.6$, and $58.8 \%$. A standard antihyperglycemic drug, glibenclamide when administered at a dose of $10 \mathrm{mg}$ per kg body weight, reduced blood glucose levels by $60.7 \%$. Thus MEIMC at the highest dose tested showed comparable activity to glibenclamide. The results are shown in Table 2 and suggest that MEIMC can be used to reduce blood glucose levels in hyperglycemic subjects.

Table 2: Effect of crude methanol extract of I. mauritiana callus (MEIMC) on blood glucose level in hyperglycemic mice following 120 minutes of glucose loading.

\begin{tabular}{lccc}
\hline \multicolumn{1}{c}{ Treatment } & $\begin{array}{c}\text { Dose (mg/kg } \\
\text { body weight) }\end{array}$ & $\begin{array}{c}\text { Blood glucose } \\
\text { level (mmol/l) }\end{array}$ & $\begin{array}{c}\text { \% lowering of } \\
\text { blood glucose } \\
\text { level }\end{array}$ \\
\hline Control & $10 \mathrm{ml}$ & $7.58 \pm 0.22$ & - \\
Glibenclamide & $10 \mathrm{mg}$ & $2.98 \pm 0.42$ & $60.7^{*}$ \\
(MEIMC) & $50 \mathrm{mg}$ & $4.92 \pm 0.83$ & $35.1^{*}$ \\
(MEIMC) & $100 \mathrm{mg}$ & $4.36 \pm 0.20$ & $42.5^{*}$ \\
(MEIMC) & $200 \mathrm{mg}$ & $3.52 \pm 0.40$ & $53.6^{*}$ \\
(MEIMC) & $400 \mathrm{mg}$ & $3.12 \pm 0.25$ & $58.8^{*}$ \\
\hline
\end{tabular}

All administrations were made orally. Values represented as mean \pm SEM, $(\mathrm{n}=5) ;{ }^{*} P<0.05$; significant compared to hyperglycemic control animals.

We have previously examined the blood glucose lowering ability of I. mauritiana tuber root powder when administered in diets of rats. Significant blood glucose lowering ability was observed when rat diet contained tuber root powder of the plant compared to control rats fed a diet without tuber root powder (Moushumi et al., 2010). The ability of MEIMC to lower blood glucose thus suggests that whatever antidiabetic phytoconstituent(s) are present in tuber root powder may also be present also in the calluses. However, the exact nature of the phytoconstituent(s) remains to be elucidated and is currently undergoing analysis in our laboratory. Interestingly, phenolic antioxidants have been reported in the plant (Sulaiman et al., 2014). Although their nature was been determined, such compounds if present in MEIMC may be responsible for the observed analgesic and antihyperglycemic effects.

\section{CONCLUSION}

The results suggest that methanolic extract of $I$. mauritiana callus can be used for lowering of blood glucose and for alleviating pain.

\section{ACKNOWLEDGEMENTS}

The authors thank Erena Islam for her help in the experiments. The authors also declare that they have no conflicts of interest.

\section{REFERENCES}

Ahmed AB, Rao AS, Rao MV. In vitro callus and in vivo leaf extract of Gymnema sylvestre stimulate $\beta$-cells regeneration and antidiabetic activity in Wistar rats. Phytomedicine, 2010; 17:1033-1039.

Ahmed F, Rahman S, Ahmed N, Hossain M, Biswas A, Sarkar S, Banna H, Khatun MA, Chowdhury MH, Rahmatullah M. Evaluation of Neolamarckia cadamba (Roxb.) Bosser leaf extract on glucose tolerance in glucose-induced hyhperglycemic mice. Afr J Trad Complement Altern Med, 2011; 8:79-81. 
Akter M, Mitu IZ, Proma JJ, Rahman SM, Islam MR, Rahman S, Rahmatullah M. Antihyperglycemic and antinociceptive activity evaluation of methanolic extract of Trichosanthes anguina fruits in Swiss albino mice. Adv Nat Appl Sci, 2014; 8:70-74.

Ali Ahmed AB, Rao AS, Rao MV. In vitro production of gymnemic acid from Gymnema sylvestre (Retz) R. Br. ex Roemer and Schultes through callus culture under abiotic stress conditions. Methods Mol Biol, 2009; 547:93-105.

Anzumi H, Rahman S, Islam MA, Rahmatullah M. Uncommon medicinal plant formulations used by a folk medicinal practitioner in Naogaon district, Bangladesh. World J Pharm Pharmaceut Sci, 2014; 3:176-188.

Azad AK, Mahmud MR, Parvin A, Chakrabortty A, Akter F, Moury SI, Anny IP, Tarannom SR, Joy SK, Chowdhury SY, Akter S, Rahmatullah M. Ethnomedicinal surveys in two Mouzas of Kurigram district, Bangladesh. World J Pharm Pharmaceut Sci, 2014; $3: 1607-1620$

Ganapaty S, Dash GK, Subburaju T, Suresh P. Diuretic, laxative and toxicity studies of Cocculus hirsutus aerial parts. Fitoterapia, 2002; 73:28-31

Ghosh D, Mandal I, Rumi JF, Trisha UK, Jannat H, Ahmed M, Rahmatullah M. Effect of Allium sativum leaf extracts on glucose tolerance in glucose-induced hyperglycemic mice. Adv Nat Appl Sci, 2014; 8:66-69.

Haque ME, Rahman S, Rahmatullah M, Jahan R. Evaluation of antihyperglycemic and antinociceptive activity of Xanthium indicum stem extract in Swiss albino mice. BMC Complement Alternat Med, 2013; 13:296-299.

Hossain AI, Faisal M, Rahman S, Jahan R, Rahmatullah M. A preliminary evaluation of antihyperglycemic and analgesic activity of Alternanthera sessilis aerial parts. BMC Complement Alternat Med, 2014; 14:169-173.

Islam S, Chawdhury MHR, Hossain I, Sayeed MSR, Rahman S, Azam FMS, Rahmatullah M. A study on callus induction of Ipomoea mauritiana: an Ayurvedic medicinal plant. Am.-Eur J Sustain Agric, 2014; 8:86-93.

Jahan N, Khan A, Hasan MN, Hossain MU, Das U, Sultana S, Rahmatullah M. Ethnomedicinal plants of fifteen clans of the Garo tribal community of Madhupur in Tangail district, Bangladesh. Am.-Eur J Sustain Agric, 2013; 7:188-195.

Jahan S, Rahmatullah M. Methanolic extract of aerial parts of Raphanus sativus var. hortensis shows antihyperglycemic and antinociceptive potential. World J Pharm Pharmaceut Sci, 2014; 3:193202.

Joy KL, Kuttan RJ. Anti-diabetic activity of Picrorrhiza kurroa extract. J Ethnopharmacol, 1999; 67:143-148.

Kelkar SM, Kaklij GS, Bapat VA. Determination of antidiabetic activity in Allium cepa (onion) tissue cultures. Indian J Biochem Biophys, 2001; 38:277-279.

Monjur-Al-Hossain ASM, Hasan MM, Khusi S, Dey A, Khan MR. Phytochemical screening and the evaluation of the antioxidant, antimicrobial and analgesic properties of the plant Ipomoea mauritiana (Family: Convolvulaceae). Int Res J Pharm, 2013, 4:60-63.

Morshed A, Hossain MH, Shakil S, Nahar K, Rahman S, Ferdausi D, Hossain T, Ahmad I, Chowdhury MH, Rahmatullah M. Evaluation of antinociceptive activity of two Bangladeshi medicinal plants, Kalanchoe pinnata (Lam.) Pers. and Lagerstroemia speciosa (L.) Pers. Adv Nat Appl Sci, 2010; 4:193-197.

Moushumi SJ, Ahmed R, Ahmed H, Ali M, Haq WM, Jahan R, Rahmatullah M. Hypoglycemic, hypocholesterolemic and hypotriglyceridemic activity of tuber roots of Ipomoea mauritiana Jacq. (Convolvulaceae) when administered to rats. Adv Nat Appl Sci, 2010; 4:174-176
Rahman S, Jahan R, Rahmatullah M. Effect of paddy husk extracts on glucose tolerance in glucose-induced hyperglycemic mice. World J Pharm Pharmaceut Sci, 2014; 3:111-120.

Rahmatullah M, Nuruzzaman M, Hossan MS, Khatun MA, Rahman MM, Jamal F, Harun-Or-Rashid M, Nasrin D, Seraj S, Jahan R. An ethnomedicinal survey of folk medicinal practitioners of Shitol Para village, Jhalokati district, Bangladesh. Adv Nat Appl Sci, 2010a; 4:85-92.

Rahmatullah M, Sultan S, Toma TT, Lucky SS, Chowdhury MH, Haque WM, Annay MEA, Jahan R. Effect of Cuscuta reflexa stem and Calotropis procera leaf extracts on glucose tolerance in glucoseinduced hyperglycemic rats and mice. Afr J Trad Complement Altern Med, 2010b; 7:109-112.

Rahmatullah M, Hosain M, Rahman S, Rahman S, Akter M, Rahman F, Rehana F, Munmun M, Kalpana MA. Antihyperglycaemic and antinociceptive activity evaluation of methanolic extract of whole plant of Amaranthus tricolour L. (Amaranthaceae). Afr J Trad Complement Altern Med, 2013a; 10:408-411.

Rahmatullah M, Hossain M, Mahmud A, Sultana N, Rahman SM, Islam MR, Khatoon MS, Jahan S, Islam F. Antihyperglycemic and antinociceptive activity evaluation of 'khoyer' prepared from boiling the wood of Acacia catechu in water. Afr J Trad Complement Altern Med, 2013b; 10:1-5.

Shahreen S, Banik J, Hafiz A, Rahman S, Zaman AT, Shoyeb MA, Chowdhury MH, Rahmatullah M. Antihyperglycemic activities of leaves of three edible fruit plants (Averrhoa carambola, Ficus hispida and Syzygium samarangense) of Bangladesh. Afr J Trad Complement Altern Med, 2012; 9:287-291.

Shanmugasundaram P, Venkataraman S. Anti-nociceptive activity of Hygrophilous auriculata (Schum) Heine. Afr J Tradit Complement Altern Med, 2005; 2:62-69.

Sulaiman C, Sivadasan PG, Balachandran I. Identification of phenolic antioxidants in Ipomoea mauritiana Jacq. Using spectrophotometric and mass spectroscopic studies. Avicenna J Phytomed, 2014; 4:89-96.

Tazin TQ, Rumi JF, Rahman S, Al-Nahain A, Jahan R, Rahmatullah M. Oral glucose tolerance and antinociceptive activity evaluation of methanolic extract of Vigna unguiculata ssp. unguiculata beans. World J Pharm Pharmaceut Sci, 2014; 3:28-37.

Venkatesh S, Reddy GD, Reddy YSR, Sathyavathy D, Reddy B. Effect of Helicteres isora root extracts on glucose tolerance in glucoseinduced hyperglycemic rats. Fitoterapia, 2004; 75:364-367.

Walid R, Suvro KFA, Harun-or-Rashid M, Mukti M, Rahman S, Rahmatullah M. Ethnomedicinal plants of folk medicinal practitioners of two villages in Bagerhat district of Bangladesh. Am.-Eur J Sustain Agric, 2013; 7:61-74

\section{How to cite this article:}

Saiful Islam, Md R Ahmed, Rahat Al-Mahamud, Shahnaz Rahman, Ferdous MS Azam, Rownak Jahan, Mohammed Rahmatullah. Callus extract of Ipomoea mauritiana show analgesic and antihyperglycemic activity in Swiss albino mice. J App Pharm Sci, 2015; 5 (10): 044-047. 